\title{
Markus Lång
}

\section{Kirjallisuudenomaisuutta on suositeltu}

Ansioitunut fennisti Erkki Lyytikäinen on parissakin yhteydessä mainostanut uudissanaansa "kirjallisuuteus", jota hän tarjoaa venäjän käsitteen литературность suomennosvastineeksi (Lyytikäinen 2010; 2011). Hän moitiskelee sanaa "kirjallisuudellisuus", jota näkee valitettavan usein tieteellisissäkin kirjoitelmissa.

Ikävä kyllä Lyytikäinen kulkee jälkijunassa. Suomen kielen lautakunta oli jo 21.1.1991 käsitellyt termiä "kirjallisuudellisuus" ja todennut sen olevan väärin muodostettu. Kielitoimisto päätti suosittaa käyttöön oikein muodostettua sanaa kirjallisuudenomaisuus.

Lyytikäisen sanasepite ei merkitse parannusta - päinvastoin. Sanassa "kirjallisuuteus" toistuu yhä edelleen kahdesti peräkkäin sama johdinaines -(U)Us : -(U)Ude-, ja sana on siksi rakenteeltaan kielenvastainen, aivan niin kuin "kirjallisuudellisuuskin".

Asiassa on epäselvää, onko kielitoimiston suositus tältä osin tosiaankin muuttunut ja miksi Lyytikäinen ei ottanut kirjoituksissaan aikaisempaan suositukseen mitään kantaa. Valitettavaa on myös se, että Hosiaisluoma (2003) ynnä muut Lyytikäisen mainitsemat lähteet jättävät kyseisen suosituksen kokonaan huomiotta, vaikka siitä on alan lehdessä tiedotettu (Töysä 1991).

\section{Lähteet}

HOSIAISLUOMA, YRJÖ 2003: Kirjallisuuden sanakirja. WSOY, Helsinki. LYYTIKÄINEN, ERKKI 20IO: Kirjallisuuden ydin: kirjallisuuteus. Avain 3, 65-66. LYYTIKÄINEN, ERKKI 2OI I: Kirjallisuuden ydin: kirjallisuuteus. Kielikello 1, $26-27$. TÖYSÄ, HARRI I99I: Sananen eräiden semiotiikkatermien suomenkielisistä vastineista. Synteesi 1-2, 205-206. 